


\title{
Judicial Protection of a Human Dignity Right
}

\section{DOI: https://doi.org/10.46398/cuestpol.3969.13}

\author{
Valeriy Mamnitskyi * \\ Iryna Cherevatenko ** \\ Natalia Horban ***
}

\begin{abstract}
Human dignity has become a central legal concept throughout the world and is increasingly used in judicial decisions in many countries that do not include it in their national legislation. However, due to the acknowledged vagueness of the concept, academics and judges have identified many difficulties in its implementation and the specific challenges it poses to the rule of law. Consequently, from a documentary methodology this article tries to develop and propose, from the analysis of different philosophical approaches to the definition of human dignity, a series of principles that can be applied in judicial decisions to achieve a deep common understanding of the usefulness of human dignity and, at the same time, tries to solve problems that are now widely recognized, both by supporters and critics of the judicial use of this concept. It is concluded that the concept of human dignity must have a decisive influence on the formation, not only of substantive law but also of procedural law. It must become a criterion for the need for measures to prevent the abuse of procedural rights, the distortion of justice and the deliberate evasion of its
\end{abstract} main task.

Keywords: rule of law; access to justice; abuse of procedural rights; human dignity; human rights.

* PhD in Law, Associate Professor at the Civil Process Department, Yaroslav Mudryi National Law University, Kharkiv, Ukraine. ORCID ID: https://orcid.org/oooo-0oo2-1455-3883. Email: Mamnitskyi_v@i.ua

** PhD (Law), Associate Professor of Civil Procedure Department, Yaroslav Mudryi National Law University, Kharkiv, Ukraine. ORCID ID: https://orcid.org/oooo-0003-2937-1529. Email: cherevatenko_iryna@meta.ua

*** PhD (Law), Associate Professor, Institute of Law, Taras Shevchenko National University of Kyiv, Ukraine. ORCID ID: https://orcid.org/oooo-0oo2-3201-498X. Email: horban@online.ua 


\section{Protección judicial del derecho a la dignidad humana}

\section{Resumen}

La dignidad humana se ha convertido en un concepto jurídico central en todo el mundo y se utiliza cada vez más en decisiones judiciales en muchos países que no la incluyen en su legislación nacional. Sin embargo, debido a la reconocida vaguedad del concepto, académicos y jueces han identificado muchas dificultades en su aplicación y los desafíos específicos que plantea al estado de derecho. En consecuencia, desde una metodología documental este artículo intenta desarrollar y proponer, a partir del análisis de diferentes enfoques filosóficos de la definición de la dignidad humana, una serie de principios que pueden ser aplicados en las decisiones judiciales para lograr un profundo entendimiento común de la utilidad de la dignidad humana y, al mismo tiempo, trata de resolver problemas que ahora son ampliamente reconocidos, tanto por los partidarios como por los críticos del uso judicial de este concepto. Se concluye que el concepto de dignidad humana debe tener una influencia decisiva en la formación, no sólo del derecho sustantivo sino también procesal. Debe convertirse en un criterio para la necesidad de medidas para prevenir el abuso de los derechos procesales, la distorsión de la justicia y la evasión deliberada de su tarea principal.

Palabras clave: estado de derecho; acceso a la justiciar; abuso de los derechos procesales; dignidad humana; derechos humanos.

\section{Introduction}

The main use of human dignity in court decisions is a phenomenon that has grown significantly in the second half of the twentieth century, after the terrible events of World War II and its inclusion in the UN Charter, the Universal Declaration of Human Rights and then in national legislation. The original function of the concept was declarative and not effective. Political philosopher Jaoques Maritain (1948) explained that the use of human dignity allows representatives of different ideological beliefs to agree on practical measures to protect human rights on a common basis, but without abandoning their philosophical worldviews.

This concept is defined neither in international regulations nor in the national legislation of most countries. Its vagueness, on the one hand, allows it to be included in international human rights instruments, and on the other hand, offers different interpretations of its meaning and possible regulatory requirements. 
This article attempts to develop and propose, based on an analysis of different philosophical approaches to the definition of human dignity, a number of principles that can be applied in judicial decision making in order to achieve a deep common understanding of the usefulness of human dignity, tries to solve problems that are now widely recognized by both supporters and critics of the judicial use of this concept. Proposals have been made to take into account the criterion for determining decent human behavior while preventing the abuse of procedural rights.

\section{Basic theoretical approaches to understanding the idea of human dignity}

Ronald Dworking (1989) noted that human rights stem from human dignity, although he acknowledged that the concept was rather vague. One of the influential approaches to dignity is the Kantian secular rational approach, which considers dignity (value) in a person's ability to think rationally, and its violation as a violation of autonomy (Hill, 2014). Some scholars have emphasized the origins of this concept from the Latin word dignitas, which means honor and status, and calls for an understanding of human dignity in terms of honor (Weisstub, 2002). Another group of scholars stressed that human dignity should be used primarily to protect people from humiliation and other actions that offend human dignity (Shultziner and Rabinovici, 2012) On the other hand, some researchers have argued that this concept is ineffective, confusing and does not justify human rights or is even dangerous, and should therefore be replaced by more precise concepts. These discussions of the historical origins of the concept of human dignity and its religious and philosophical significance can be called not endowed with a legal form in the sense that they are separated from the legal application of this concept in a court decision (Rosen, 2013).

Most authors support the dual nature of human dignity: as a phenomenon objective and common to all people (value, principle, source of human rights, their purpose or content) and as a subjective right or interest of a particular person (human dignity). Sometimes researchers, when describing the essence of human dignity, use several of the above concepts simultaneously (Gryshchuk, 2018).

There are the following main theoretical approaches to understanding the idea of human dignity: theological, philosophical and legal. Representatives of the theological approach consider the idea of human dignity through the prism of Christianity, which radically changed the attitude to a person, proclaiming the equality of people before the one God, regardless of their social status, but not yet among themselves. Human 
dignity is manifested in the fact that man was created in the image and likeness of God and endowed with the basic features, which are soul, mind and free will (Maxeiner, 2008).

One of the creators of the theological (Christian) concept of human dignity was Thomas Aquinas. It is widely known his ideas of human dignity: that each person has not only divine dignity in its original source, but also has an integral natural right to dignity; natural law commands respect for human dignity; the most obvious sign of the social status of the person through whom human dignity is manifested in freedom; freedom is most fully respected in civil society; the purpose of the state is to provide conditions for a dignified human life; recognize the people`s "right to disobey" the tyrannical government, which degrades their dignity.

The philosophical approach to the idea of human dignity is most prominently represented in the philosophy of I. Kant, J. Rawls and J. Habermas. In particular, Kant proposed a holistic concept of human dignity and in fact made it part of the European culture. One of the central elements of the modern concept of human dignity has been the recognition of the object of dignity as an end in itself and the recognition that the object of dignity cannot be considered in a purely instrumental way (HennetteeVauchez, 2014).

J. Rawls proved that self-esteem is an important primary good and includes two aspects: 1) it includes a person's sense of self-importance and the belief that their concept of self-worth, life plan deserves to be realized, and they are respected by other people; 2 ) self-esteem includes confidence in one's own abilities and fulfillment of one's own intentions. In addition, each person seeks to avoid social conditions that undermine his or her selfesteem (Rhoda, 1992).

According to the concept of J. Habermas, the normative source of modern human rights is the idea of human dignity. Human rights are seen as those that should serve to protect human dignity. This evokes human self-esteem and social recognition of the international status of a democratic state. Human dignity is seen as a realistic utopia, the necessary goal of which is the realization of social justice inherent in the institutions of a democratic state (Weisstub, 2002).

The legal approach considers human dignity in two ways: as an objective phenomenon (anthropic dignity, dignity as a value, principle, source of human rights, their purpose or content) and as a subjective phenomenon (human right).

Human dignity as an objective phenomenon (anthropic dignity, dignity as a value, principle, source of human rights, their purpose or content) is considered through the relationship with the system of human rights and freedoms. To explain the nature of this connection, it is appropriate to apply 
the often-used comparison of human dignity with a tree, "the branches of which are human rights. Human dignity pulsates in human rights, which means that it is the deepest reason for their protection" (Granat, 2016). Such a metaphor helps to understand the absolute nature of human dignity, regardless of the peculiarities of the legal regulation of human rights and freedoms, and also emphasizes its supranational or suprapositive nature. Recognition of the innateness and integral nature of human dignity means the recognition of its natural law nature. Dignity is something given, objective, not created, but a recognized positive right. Recognition of dignity is the recognition of a legally significant certain property of a person, especially important for determining the conditions of human development (Piechowiak, 2012).

It should be agreed that human dignity is a common constitutional value, which is the source, basis and principle of the entire constitutional order. This is the basic norm in the logical, ontological and hermeneutic senses. Therefore, not only other principles of the system of human rights and freedoms, but also certain specific rights and freedoms should be interpreted through the prism of the principle of dignity and should be used to ensure its implementation (following the constitutional definition of dignity as a source of freedom and human and civil rights), but also all other norms, principles and values contained in the constitution must be interpreted and applied in accordance with the principle of dignity (Garkicki, 2015).

The constitutional significance of human dignity has a central normative role. Human dignity as a constitutional value is a factor that unites human rights into a single whole, which ensures their normative unity. This normative unity is expressed in three ways: first, the value of human dignity serves as the normative basis of the constitutional rights set forth in the constitution; second, it serves as an explanatory principle for determining the scope of constitutional rights, including the right to human dignity; third, the value of human dignity plays an important role in determining the proportionality of the statute that limits constitutional law (Barak, 2015).

In addition to scientific and philosophical views, judges are increasingly turning to the concept of human dignity in various areas of law. However, with the increase in its use, especially since the 1990s, there have also been difficulties in its application. Judges of different legal systems have recognized that this concept is difficult to define, and this creates problems for the interpretation of law, legal certainty and the principle of the rule of law. European Court of Human Rights in Vereinigung Bildender Ktlnstler v. Austria (2007) notes that an abstract or vague notion of human dignity can be dangerous in itself, as it can be used as an imposition of unacceptable restrictions on fundamental rights. The Supreme Court of Canada in R. v. Kapp (2008) acknowledged that "human dignity is an abstract and subjective concept that can not only be misleading but difficult to apply, it also confirms the additional burden on those who seek equality. 
Indeed, increasing attention to human dignity seems to be created by problems in terms of its compliance with the rule of law. One of the main problems pointed out by critics is the lack of sufficient legal certainty about respect for human dignity. Legal certainty is a principle that stipulates that legislation should be clear and sufficiently predictable so that citizens can act confidently in their lives and without fear of breaking the law without knowing what it really means. As Joseph Ratz (1977) pointed out, in order for the law to be obeyed it must be able to guide the behavior of its citizens, it must be such that they can learn what it is and act accordingly. This principle is considered to be the international basis of the rule of law. It requires that laws and their application serve as a guide and "allow those to whom the law applies to plan their lives with less uncertainty," and protect them "from the arbitrary use of state power". Vague and open legal norms allow public authorities to prosecute people for breaking the law without clear criteria. Similarly, the US Supreme Court in City of Akron v. Akron Ctr. (1983) repealed the ban on abortion in the city of Akron. One of the provisions was that doctors should dispose of embryo residues "in a humane and sanitary manner." The court ruled that the term "humane", which is very close to human dignity, was used unconstitutionally and vaguely as "a definition of conduct to be prosecuted" because doctors could not understand from the law whether their actions were lawful or not.

The concept of human dignity is quite debatable due to the problem of legal certainty, its uncertain or unclear nature. The free use of this term in the preparation of draft laws and judicial decisions is the result of confusion and uncertainty about the basic meaning of the term "dignity"; this limits the scope for comparative constitutional analysis and leads to a lack of harmony between national and international human rights debates. French judge Christian Byk (2014), who advocates respect for dignity, recognizes that there is no doubt that the law requires certainty and predictability, and that an understanding of the concept of human dignity from a more precise legal point of view would contribute to the implementation of legal norms. Jack Donnelly (1986) also explains that human dignity cannot in fact form the basis of human rights in any sense, because there is no logical connection between human dignity and human rights, either theoretically or empirically. The main problem with Donelli's approach is that people around the world do not always view human rights with the notion of human dignity. In addition, vague references to any concept to achieve the desired goal are problematic from the point of view of the rule of law.

This concept has not been defined in international law, national constitutions, or doctrinal interpretations. The lack of a coherent working definition of human dignity in any country in the world has led to an uncontrolled variety of applications. The term is used inconsistently for the same issues, such as abortion, euthanasia, incitement and freedom of speech, obscenity, and social rights and free enterprise (Carozza, 2008). 
Vague and inconsistent interpretations of human dignity are a more serious threat to the rule of law than other broad concepts such as equality, freedom, freedom of speech and privacy. First, broad rights such as equality and freedom have a clearer meaning in the enduring doctrines of application that have evolved over the centuries. On the other hand, human dignity was reflected in legal norms rather late in court decisions in the late 2oth century. Second, human dignity has no clear boundaries. It is not limited to any particular right or branch of law, but it can be and is linked to almost all human rights; its vagueness performs a symbolic function that is usually not suitable for complex legal issues. This is probably why judges in most countries have failed to develop a doctrine of human dignity or a consensus on its meaning or limits (Brect, 1980). For example, an attempt to elevate human dignity to constitutional value in France has been rejected by legal experts precisely because of its ambiguity and its potential restrictions on individual freedoms. Third, despite the fact that judges increasingly refer to the principle of respect for human dignity, despite the lack of clear operational or effective legal rules governing this concept, it is often interpreted in different ways that do not necessarily comply with the law.

\section{Principles of understanding and application of the concept of "human dignity"}

Problems related to the use of human dignity in court decisions can be solved by developing certain principles that were proposed by Doron Shultziner (2017). This approach is worthy of support, as well as further improvement, which we tried to offer in this part of our study.

Thus, according to Doron Shultziner (2017), the purpose of these principles is to help achieve a deeper understanding of the usefulness of human dignity from theoretical and philosophical understandings to a more practical and legal framework. The development of common and agreed principles for the application of human dignity will allow us to address the question of how to constructively apply this concept and try to solve problems that are now widely recognized by both supporters and critics of the judicial use of this concept. The following principles are complementary, but each can be useful independently from the others:

Principle 1: The application of the principle of respect for human dignity in judicial decisions should be based on written law.

Principle 2: Judges should try to define what constitutes human dignity and clearly define its meaning.

Principle 3: Judges should strive to consistently use human dignity in the same court decisions and in subsequent enforcement. 


\section{2 \\ Valeriy Mamnitskyi, Iryna Cherevatenko y Natalia Horban \\ Judicial Protection of a Human Dignity Right}

them.

Principle 4: Human dignity should promote human rights, not limit

These principles are formalized and quite narrow in terms of their regulatory requirements, they meet most basic concepts of dignity.

In general, supporting the proposed concept, we believe that of the four principles, principle 4 is the most normative or based on certain values. It requires that human dignity be used to promote human rights, not to restrict them. The original function of human dignity is revealed primarily in the European Convention for the Protection of Human Rights and Fundamental Freedoms and in most national laws. The purpose of this principle is to bring human dignity into line with human rights so that it is not tied to functions that restrict human rights.

\section{Application of the concept of "human dignity" in the judicial practice of Ukraine}

It is illogical to consider human dignity as a restriction of human rights. However, as we shall see, the open nature and function of the concept allows judges to refer to it also as an excuse to restrict rights or it may lead to such restrictions without intent.

Disrespect for human dignity through the use of offensive words towards the court or participants in the process, in accordance with the procedural legislation of Ukraine (Izarova, 2019), is a manifestation of abuse of procedural rights (Rozhnov, 2020). Thus, in the decision from 13.03.2019 (case № 199/6713/14-c), the Grand Chamber of the Supreme Court draws attention to the fact that the use of obscene language, abusive words or symbols by court participants and their representatives in documents submitted to the court and in communication with the court (judges), other participants in the process and their representatives, as well as the commission of similar actions is a manifestation of obvious disrespect for the honor, dignity of these persons by those who commit such acts. These actions contradict the basic guidelines (principles) of civil proceedings (paragraphs 2, 11, part 3 of Article 2 of the CPC of Ukraine), as well as its task, which prevails over any other considerations in the trial (parts one and two of this articles). In view of this, the court may recognize the commission of such actions as an abuse of procedural rights and apply the consequences provided for in part three of Article 44 of the CPC of Ukraine.

The consequences of disrespect for human dignity in civil cases are to leave the claim without consideration. As an example, we can cite the decision of the Kryvyi Rih District Court of Dnipropetrovsk Region (2020) in the case № 216/5339/14-c. Thus, leaving without consideration the 
complaint of PERSON_1 on illegal actions of the state executor, cancellation of the decision to initiate enforcement proceedings, the court notes that in his statements in court, the applicant PERSON_1 systematically used abusive statements and baseless accusations against the presiding judge and other judges of the Kryvyi Rih District Court of the Dnipropetrovsk Region, made threats and provocative statements, which is unacceptable. Such procedural behavior of the applicant PERSON_1 indicates that he appealed to the court not to protect his violated rights. The mentioned regards as a ground for procedural rights abusing traditionally (Gajda Roszczynialska, 2019).

The statements used by PERSON_1 go beyond normal, specific, and legitimate criticism, which, in particular, in the understanding of the European Court of Human Rights (hereinafter - ECtHR), is stated as an abuse of the right to file an application. Thus, the ECtHR, in application of Article 35 clause 3 subclause 'a' of the Convention for the Protection of Human Rights and Fundamental Freedoms, declares inadmissible any individual application submitted under Article 34 if it considers that the application is an abuse of the right to submit an application. For example, the ECtHR finds an abuse of the right to file an application when the applicant uses insulting, threatening or provocative statements against the respondent government, its representative, the respondent State authorities, the ECtHR, its judges, the ECtHR Secretariat or its staff (decisions on admissibility in Rehak v. the Czech Republic of 14 May 2004, application № 67208/01); of 4 February 2003 application № 61164/o0 and № 18589/02).

\section{Conclusions}

The study shows that the concept of human dignity should have a decisive influence on the formation of not only substantive law but also procedural one, in particular, it must become a criterion for the necessity of measures to prevent procedural rights abuse, distortion of justice and deliberate evasion of its main task. Fourth, compared to other concepts, human dignity is more problematic because its understanding includes a worldview of what it means to be human and what a dignified existence and decent moral behavior is. This is evidenced by the decisions of national courts, in which religious and secular, social and liberal conceptions of human dignity contradict each other. The importance of human dignity is linked to ideology and, therefore, a higher risk of involving judges' personal beliefs in legal interpretation. The repeated use of the applicant's insulting statements and accusations, as well as threats and provocative statements against the court in the application on the merits and in court is considered by the court as disrespect to the court and other participants in the process and the court finds that the submission of such statements as behavior of 
Valeriy Mamnitskyi, Iryna Cherevatenko y Natalia Horban
234 Judicial Protection of a Human Dignity Right

applicant in the process, is an abuse of his last procedural right, failure to comply with the task of civil proceedings.

\section{Bibliographic References}

BARAK, Aharon. 2015. Dignity: The Constitutional Value and the Constitutional Right. Cambridge University Press. Cambridge, UK.

BRECT, Paul. 1980. Accommodation of the Majoritarianism and Rights of Human Dignity. P 53, 761.

BYK, Christian. 2014. Human Dignity a Useless Concept? Legal Perspective. In M., Duwell (ed.). The Cambridge Handbook of Human Dignity: Interdisciplinary Perspectives/ P 364.

CAROZZA Paolo G.. 2008. Human Dignity and Judicial Interpretation of Human Rights: A Reply. Eur. J. Int ' l. L931. City of Akron v. Akron Ctr. for Reprod (1983). Health, 462 U.S. 416, at sec. VII.

DONNELLY, Jack. 1986. "Human Dignity, Human Rights and Political Regimes” In: Am. Pol. Scd. Rev. No. 80, p. 801.

DWORKING, Ronald. 1989. Taking Rights Seriously. In M., Winston (ed.). The philosophy of human rights. Wadsworth Pub Co. UK.

GAJDA - ROSZCZYNIALSKA, Katarzyna. 2019. "Abuse of procedural rights in Polish and European civil procedure law and the notion of private and public interest" In: Access to Justice in Eastern Europe. No. 2 (3), pp. 53-85. Available online. In: http://ajee-journal.com/upload/attaches/ att_1560677855.pdf. Consultation date: 02/12/2020.

GARKICKI, Leszek. 2015. Polskie prawo konstytucyjne: Zaryswykładu. Wolters Kluwer. Warszawa, Poland.

GRANAT, Myroslav. 2016. The value of human dignity in constitutional law. Ukrainian Journal of Constitutional Law 1, 60. Available online. In: http:// www.constjournal.com/wp-content/uploads/2016/11/GranatM.-Znachennya- gidnosti-lyudyny-u-konstytutsijnomu-pravi.pdf. Consultation date: 02/12/2020.

GRYSHCHUK, Oksana. 2018 Human Dignity in Law: Philosophical and Legal Protection. Human dignity and human rights as the basis of the constitutional system of the state (a collection of abstracts of the International scientific-practical conference "Human dignity and human rights as the basis of the constitutional system of the state"). Khmelnytsky University of Management and Law. Khmelnytsky, Ukraine. 
HENNETTEE-VAUCHEZ, Stéphanie. 2014. Human Dignity in French Law. In M., Duwell (ed.). The Cambridge Handbook of Human Dignity: Interdisciplinary Perspectives. Cambridge, UK.

HILL, Thomas E. 2014. Kantian Perspective on the Rational Basis of Human Dignity. In M., Duwell, et al. The Cambridge Handbook of Human Dignity: Interdisciplinary Perspectives. Cambridge University Press. Cambridge, UK.

IZAROVA, Iryna. 2019. Reform of Civil Justice in Ukraine: A Differentiation of Action Proceedings and Review of Court Decisions. Teise (Law), 111, 234-245. Available online. In: https://www.journals.vu.lt/teise/article/ view/12828. Consultation date: $02 / 12 / 2020$.

MARITAIN, Jaoques. 1948. Introduction. In Human Rights: Comments and Interpretations - A symposium (UNESCO ed.).

MARITAIN, Jaoques. 1951. Man and the State. Chicago University Press. Chicago, USA.

MAXEINER, James. 2008. "Some Realism About Legal Certainty in the Globalization of the Rule of Law” In: Hous. J. Int `l. L. Vol. 31, p. 26.

PIECHOWIAK, Marek. 2012. Dobro wspó lne jako fundament polskiego porza $\square$ dku konstytucyjnego. Tom XI Studio w w Materiało w Trybunału Konstytucyjnego 2. Biuro Trybunału Konstytucyjnego, pp. 310-494. R. v. KAPP 2 S.C.R. 483 (Can.). Art. 19, 2008. P. 21, 22.

RATZ, Joseph. 1977. "Rule of Law and Its Virtue" In: L.Q. RevP. Vol. 93, pp. 195-220.

RHODA, Howard. 1992. Howard, Dignity, Community, and Human Rights. In A.A., An-Na'im (ed.). Human rights in Crosscultural Perspective: A Request for Concensus. University of Pennsylvania Press. Philadelphia, USA.

ROSEN, Michael. 2013. Dignity: The Case Against. In Ch., McCrudden (ed.). Understanding Human Dignity. Oxford: Oxford University Press. Greaty, C. (2013). Socio-Economic Rights, Basic Needs, and Human Dignity: A Perspective from Law's Front Line. In Ch., McCrudden (ed.). Understanding Human Dignity. Oxford University Press. Oxford, UK.

ROZHNOV, Oleh. Towards Timely Justice in Civil Matters Amid the COVID-19 Pandemic. In: Access to Justice in Eastern Europe. Vol. 2-3, No. 7, pp. 100-114. Available online. In: http://ajee-journal.com/upload/attaches/ att_1599502312.pdf. Consultation date: 02/12/2020. 
Valeriy Mamnitskyi, Iryna Cherevatenko y Natalia Horban

236 Judicial Protection of a Human Dignity Right

SHULTZINER, Doron. 2017. "Human Dignity in Judicial Decisions: Principles of Application and the Rule of Law” In: Cardozo J. Int 'l. L. \& Comp. L. No. 25, p.435.

SHULTZINER, Doron; RABINOVICI, Itai. 2012. Human Dignity, Self-Worth, and Humiliation: A Comparative Legal-Psychological Approach. Psychol. Pub. Poly \& L. 18. P.105 The decision in the case № 216/5339/14-c (2020). Kryvyi Rih District Court of Dnipropetrovsk region. Available online. In: http://reyestr.court.gov.ua/Review/91624861. Consultation date: $02 / 12 / 2020$.

VEREINIGUNG BILDENDER KUNSTLER v. AUSTRIA App. 2007. No. 68354/o1 (ECHR, Spielmann, J. \& Jebens, J., dissenting at 9).

WEISSTUB, Honor. 2002. Dignity and the Framing of Multiculturalist Values. In D., Kretzmer, E., Kleineds. The Concept of Human Dignity in Human Rights Discourse. Kluwer Law International. New York, USA. 
Vol. 39 N $^{\circ} 69$

Esta revista fue editada en formato digital y publicada en julio de 2021, por el Fondo Editorial Serbiluz, Universidad del Zulia. Maracaibo-Venezuela 